\title{
¿

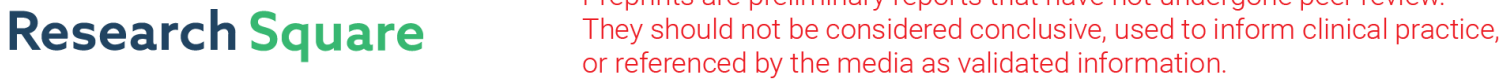 \\ Do Laboratory Biomarkers Predict Survival in Severe COVID-19? A Cross-sectional Study
}

\section{Sher Bahadur}

Khyber Institute of Child Health

Fawad Rahim ( $\nabla$ drfawadrahim@outlook.com )

Assistant Professor, Department of Medicine, Hayatabad Medical Complex, Peshawar, Pakistan. https://orcid.org/0000-0002-4972-1656

\section{Said Amin}

Hayatabad Medical Complex

\section{Mohammad Noor}

Hayatabad Medical Complex

\section{Afsheen Mahmood}

Khyber Girls Medical College

Huma Gul

Khyber Girls Medical College

\section{Muhammad Usman}

Hayatabad Medical Complex

\section{Muhammad Asif Khan}

Hayatabad Medical Complex

\section{Raza Ullah}

Hayatabad Medical Complex

\section{Khalid Shahab}

Hayatabad Medical Complex

\section{Anwar Ul Haq}

Hayatabad Medical Complex

\section{Research article}

Keywords: COVID-19, SARS-CoV-2, Lymphopenia, C-reactive protein, Lactate Dehydrogenase, D-dimer

Posted Date: September 9th, 2020

DOl: https://doi.org/10.21203/rs.3.rs-67563/v1

License: (9) This work is licensed under a Creative Commons Attribution 4.0 International License. Read Full License 
Page $2 / 10$ 


\section{Abstract}

\section{Background}

Available research compared serum biomarkers such as lymphocyte count, C-reactive protein, ferritin, Lactate Dehydrogenase and D-dimers to predict survival in patients with mild, moderate and severe COVID-19. This study aims to compare these biomarkers among survivors and non-survivors of severe COVID-19.

\section{Methods}

This was a cross-sectional study based on patient's data retrieved from Hospital Information System. Sixty-nine patients for whom a record of the biomarkers and survival status was available, were included in the study. For every patient, baseline and peak values were selected for CRP level, serum ferritin level, serum LDH level and serum D-Dimer level. Similarly, baseline and trough levels were selected for lymphocytes. Data were analyzed using SPSS version 21. Mean and standard deviation was used to compare the biomarkers with paired $t$-test. $P$ value less than 0.05 was taken as significant.

\section{Results}

The mean age of the study population was $55.5 \pm 9.1$ years and $72.5 \%$ were male. Among survivors, the increase in CRP level was not significant (from $15.80 \pm 9.8 \mathrm{mg} / \mathrm{dl}$ to $17.87 \pm 8.4 \mathrm{mg} / \mathrm{dl}, \mathrm{p}=0.45$ ) while among the non-survivor, the increase in CRP level was significant (from $16.68 \pm 10.90 \mathrm{mg} / \mathrm{dl}$ to $20.77 \pm 12.69 \mathrm{mg} / \mathrm{dl}, \mathrm{p}=0.04$ ). There was no significant rise in serum LDH levels in survivors (from $829.59 \pm 499 \mathrm{U} / \mathrm{L}$ to $1018.6 \pm 468 \mathrm{U} / \mathrm{L}, \mathrm{p}=0.20$ ) while there was a statistically significant increase in serum $\mathrm{LDH}$ level in non-survivors (from 816.2 $\pm 443.08 \mathrm{U} / \mathrm{L}$ to $1056.61 \pm 480.54 \mathrm{U} / \mathrm{L}, \mathrm{p}=0.003$ ). Lymphocyte count decreased significantly in both survivors $(p=0.001)$ and non-survivors $(p=0.001)$. There was no statistically significant elevation in serum ferritin among the survivors and non-survivors $(p>0.05)$. The D-Dimer level increased significantly in both survivors $(p=0.01)$ and non-survivors $(p=0.001)$.

\section{Conclusions}

In severe COVID-19 patients, serum CRP and LDH can be used for risk stratification and predicting survival. Lymphopenia, increase in serum ferritin and D-dimers may not predict survival.

\section{Trial Registration}

Not applicable

\section{Background}

Corona Virus Disease 2019 (COVID-19) originated as unusual pneumonia in the visitors of a seafood market which was also selling live wild animals in Wuhan, China. Soon it was realized that human to 
human transmission does occur as similar symptoms appeared in those who got in contact with the cases \& never visited the market. ${ }^{1}$ Shortly after China, it spread across the globe \& was announced as pandemic on March 11,2020. ${ }^{2}$ As of August 25, 2020 there are 23,518,343 confirmed cases globally and 810,492 deaths worldwide. ${ }^{3}$ In Pakistan, there are 293,711 confirmed cases of COVID-19, and death tally of $6,255 .^{4}$

Corona Virus Disease 2019 has posed medical, social and scientific challenges all over the world due to its complex and unpredictable clinical course. Multiple factors have been proposed for the complex and ill-defined course of the illness. ${ }^{5}$ In the most of the cases, the disease is fairly mild, while in the rest it results in severe disease leading to multiorgan failure and death. ${ }^{6}$ Apart from gender, age, blood groups, and co-morbidities, a plethora of laboratory markers have been investigated to predict the course and outcome of the disease. $^{7-10}$

Infection with SARS CoV-2 leads to the release of cytokines and chemokines from monocytes, lymphocytes and macrophages resulting in an inflammatory response. ${ }^{11}$ The common laboratory parameters which are supposed to be linked with worse outcome in COVID-19 include C-reactive protein (CRP), interleukin-6 (IL-6), D-dimer, fibrinogen, Lactate Dehydrogenase (LDH), Cardiac Troponin, lymphocyte count, serum ferritin, serum amyloid A (SAA) and erythrocyte sedimentation rate (ESR). ${ }^{12}$ However, there is no clarity as the results of most of the studies are inconsistent. ${ }^{1,5,10,12,13}$ Laboratory predictors for outcome in terms of survival need a comprehensive investigation.

The course of SARS-CoV-2 in Pakistan is different from the developed world. The cases have declined (from 6,825 new cases per day on June 13th, 2020 to 450 new cases on August 24th, 2020) ${ }^{4}$ in the last few weeks. The seropositivity is reported as $11 \%^{14}$ in the general population which indicates that herd immunity is still to be achieved. On the other hand, adherence to standards operating procedures (SOPs) for SARS- CoV-2 were also not visible in most of the areas. This discrepancy from the rest of the world could be linked to the genetics of the population as well as that of the virus. We presume that the pattern of immune response in infected individuals may also vary in the same manner. This necessitates developing a profile of inflammatory markers of the local population and comparing it with the rest of the published literature.

\section{Methods}

Electronic record of the patinets was used for this cross-sectional study. All confirmed cases of severe COVID-19 as per WHO criteria ${ }^{15}$ in COVID - intensive care unit (COVID-ICU) of Hayatabad Medical Complex (HMC), Peshawar were eligible for inclusion in the study. The data were retrieved from Hospital Information System (HIS). The laboratory markers included in the study were lymphocyte count, CRP level, serum ferritin level, serum LDH level and serum D-dimer level. The outcome of patients was classified as survivor and non-survivor. Survivor was defined as a patient who was discharged from the hospital following improvement in symptoms. Non-survivor was defined as a patient who died during 
hospital stay with COVID-19 as a predominant contributory factor in death. Sixty-nine patients admitted in COVID-ICU, for whom data of proposed laboratory markers and outcome was available, were included in the study. All patients received standard treatment for severe COVID-19. For every patient, baseline and peak values were selected for CRP level, serum ferritin level, serum LDH level and serum D-Dimer level. Similarly, baseline and trough levels were selected for lymphocytes. Analysis was carried out in SPSS version 21.0. Descriptive statistics were performed for age, gender and co-morbidities, and results were presented as Means \pm SD and percentages. Paired t-test was applied for comparison of means of study variables (lymphocyte count, serum CRP level, ferritin, LDH and d-dimer levels) in each group (survivors and non-survivors). P value below 0.05 was considered significant.

\section{Results}

A total of 69 patients' data from COVID-ICU were studied, having a mean age of $55.5 \pm 9.1$ years. Among them, $72.5 \%$ were male, $68.1 \%$ were above 50 years age and $10.1 \%$ were diabetics. (Table 1 ).

Table 1

Demographic parameters of the study population $(n=$ 69)

\begin{tabular}{|lll|}
\hline Parameters & Frequency & Percentage \\
\hline Gender & & \\
\hline Male & 50 & $72.5 \%$ \\
\hline Female & 19 & $27.5 \%$ \\
\hline Age groups & & \\
\hline Up to50 years & 22 & $31.9 \%$ \\
\hline Above 50 years & 47 & $68.1 \%$ \\
\hline Comorbidities & & \\
\hline Diabetes & 07 & $10.1 \%$ \\
\hline Hypertension & 04 & $5.8 \%$ \\
\hline Ischemic heart disease & 03 & $4.3 \%$ \\
\hline Chronic kidney disease & 02 & $2.9 \%$ \\
\hline
\end{tabular}

The lymphocyte count decreased significantly in both survivors (from $0.94 \pm 0.36 \times 10^{9} / \mathrm{L}$ to $0.51 \pm 0.28 \times$ $10^{9} / \mathrm{L}, \mathrm{p}=0.001$ ) and non-survivors (from $1.24 \pm 0.80 \times 10^{9} / \mathrm{L}$ to $0.61 \pm 0.55 \times 10^{9} / \mathrm{L}, \mathrm{p}=0.001$ ). Among survivors, the increase in CRP level was not significant (from $15.80 \pm 9.8 \mathrm{mg} / \mathrm{dl}$ to $17.87 \pm 8.4 \mathrm{mg} / \mathrm{dl}, \mathrm{p}=$ 0.45 ) while among the non-survivors, the increase in CRP level was significant (from $16.68 \pm 10.90 \mathrm{mg} / \mathrm{dl}$ to $20.77 \pm 12.69 \mathrm{mg} / \mathrm{dl}, \mathrm{p}=0.04$ ). There was no significant rise in serum ferritin among the survivors and non-survivors $(p>0.05)$. There was no significant rise in serum LDH levels in survivors (from $829.59 \pm$ 
$499 \mathrm{U} / \mathrm{L}$ to $1018.6 \pm 468 \mathrm{U} / \mathrm{L}, \mathrm{p}=0.20$ ) while there was a statistically significant increase in serum LDH level in non-survivors (from 816.2 $\pm 443.08 \mathrm{U} / \mathrm{L}$ to $1056.61 \pm 480.54 \mathrm{U} / \mathrm{L}, \mathrm{p}=0.003$ ). The $\mathrm{D}$-Dimer level increased significantly in both survivors and non-survivors (from $7.2 \pm 9.8 \mu \mathrm{g} / \mathrm{ml}$ to $28.8 \pm 35.4 \mu \mathrm{g} / \mathrm{ml}, \mathrm{p}=$ 0.01 and from $8.75 \pm 14.8 \mu \mathrm{g} / \mathrm{ml}$ to $29.52 \pm 37.96 \mu \mathrm{g} / \mathrm{ml}, \mathrm{p}=0.001$, respectively). (Table 2 )

Table 2

Laboratory parameters in survivors and non-survivors

\begin{tabular}{|c|c|c|c|c|c|c|}
\hline \multirow[t]{3}{*}{ Parameters } & \multicolumn{2}{|l|}{ Survivors } & \multirow{3}{*}{$\begin{array}{l}\text { P- } \\
\text { Value }\end{array}$} & \multicolumn{2}{|l|}{ Non-survivors } & \multirow{3}{*}{$\begin{array}{l}\text { P- } \\
\text { Value }\end{array}$} \\
\hline & Baseline & Peak/Trough & & Baseline & Peak/Trough & \\
\hline & Mean \pm SD & Mean \pm SD & & Mean \pm SD & Mean \pm SD & \\
\hline Lymphocytes & $0.94 \pm 0.36$ & $0.51 \pm 0.28$ & 0.001 & $1.24 \pm 0.80$ & $0.61 \pm 0.55$ & 0.001 \\
\hline CRP & $15.80 \pm 9.8$ & $17.87 \pm 8.4$ & 0.45 & $16.68 \pm 10.90$ & $20.77 \pm 12.69$ & 0.04 \\
\hline Ferritin & $\begin{array}{l}1321.13 \pm \\
1443\end{array}$ & $\begin{array}{l}2141.18 \pm \\
3521\end{array}$ & 0.31 & $\begin{array}{l}1227.01 \pm \\
1064.16\end{array}$ & $1662.7 \pm 21$ & 0.12 \\
\hline LDH & $\begin{array}{l}829.59 \pm \\
499\end{array}$ & $1018.6 \pm 468$ & 0.20 & $816.2 \pm 443.08$ & $\begin{array}{l}1056.61 \pm \\
480.54\end{array}$ & 0.003 \\
\hline D-Dimer & $7.2227 \pm 9.8$ & $28.8 \pm 35.4$ & 0.01 & $8.75 \pm 14.8$ & $29.52 \pm 37.96$ & 0.001 \\
\hline
\end{tabular}

\section{Discussion}

The results of the present study were based on laboratory parameters of 69 confirmed cases of COVID-19 admitted to ICU. Lymphocyte count was significantly decreased in both survivors and non-survivors ( $p<$ 0.001). Similar findings were reported by Huang and Pranata ${ }^{16}$ who observed that lymphopenia is found to be the key predictor for the severity of COVID-19 and is associated with poor outcomes. They reported that cases with worse outcome have a lower lymphocyte count with a mean difference $=-361.06$ per $\mu \mathrm{L}$ $(95 \% \mathrm{Cl}-439.18,-282.95 ; p<0.001 ;)$ when compared to cases with favorable outcome. Research conducted by Zhou et al. ${ }^{1}$ revealed that cases with COVID-19 who did not survive had lower lymphocyte count in comparison to survivors ( 0.6 vs $\left.1.1 \times 10^{9} / \mathrm{L}, \mathrm{P}<0.0001\right)$. In contrast to Zhou et al. where patients with all stages of COVID-19 were studied, the patients included in this study had only severe disease. Moreover, we determined the maximum drop in lymphocyte count from basline in both groups. The potential mechanisms of lymphopenia in COVID-19 are; direct destruction of lymphocytes by the virus, injury to the lymphatic organs, ${ }^{16}$ abnormalities of cytokines leading to lymphocyte depletion, ${ }^{17}$ and lactic acidosis secondary to hypoxemia. ${ }^{18}$

In the present study significant rise in CRP was found to be a marker of non-survival. There was significant increase (from $16.68 \pm 10.90 \mathrm{mg} / \mathrm{dl}$ to $20.77 \pm 12.69 \mathrm{mg} / \mathrm{dl}, \mathrm{p}=0.04$ ) in non-survivor as compared to survivors $(p=0.45)$. The association of CRP with poor outcomes in COVID-19 has already 
been reported by Li et al., Feng et al., Chen et al and Wang. ${ }^{7,8,19,20}$ Research suggests that CRP is one of the most important biomarkers to predict the prognosis of COVID-19. ${ }^{10}$

The serum ferritin increased from the baseline in survivors and non-survivors, but the rise in both groups was not significant. ( $p=0.31$ and $p=0.12$, respectively). This contrasts with Zhou et al. ${ }^{1}$ who have reported significantly elevated serum ferritin in non-survivors as compared to survivors $(1435 \mathrm{ng} / \mathrm{ml}$ and $503 \mathrm{ng} / \mathrm{ml}$, respectively; $\mathrm{p}$ < 0.0001). Similarly, Chen et al. ${ }^{12}$ have observed higher serum ferritin in patients with severe illness as compared to those with moderate disease (serum ferritin $>800 \mathrm{ng} / \mathrm{ml}$ in $100 \%$ of patients with severe disease versus $30 \%$ in those with moderate disease, $p=0.003$ ). The difference could be due to a difference in the case selection. We included only patients with severe disease while $93 \%$ of survivors in the study conducted by Zhou et al. ${ }^{1}$ had mild disease (CURB score $0-1$ ) and $48 \%$ of the participants included by Chen et al. ${ }^{12}$ were having non-severe disease.

There was a statistically significant increase in serum LDH level in non-survivors (from $816.2 \pm$ $443.08 \mathrm{U} / \mathrm{L}$ to $1056.61 \pm 480.54 \mathrm{U} / \mathrm{L}, \mathrm{p}=0.003$ ) as compared to survivors (from $829.59 \pm 499 \mathrm{U} / \mathrm{L}$ to $1018.6 \pm 468 \mathrm{U} / \mathrm{L}, \mathrm{p}=0.20$ ). According to a study from China ${ }^{1}$, serum LDH level was significantly higher among non-survivors $(p<0.001)$. Similarly, it has been reported that high LDH level is associated with Acute respiratory distress syndrome, admission to intensive care unit, progression of the disease and higher mortality. ${ }^{1,9,21-23}$

The D-Dimer level increased significantly in both survivors and non-survivors (from $7.2 \pm 9.8 \mu \mathrm{g} / \mathrm{ml}$ to $28.8 \pm 35.4 \mu \mathrm{g} / \mathrm{ml}, \mathrm{p}=0.01$ and from $8.75 \pm 14.8 \mu \mathrm{g} / \mathrm{ml}$ to $29.52 \pm 37.96 \mu \mathrm{g} / \mathrm{ml}, \mathrm{p}=0.001$, respectively). Published literature indicates that D-Dimer levels were significantly higher among those with severe disease. 1,5,7,10,21 This discrepancy may be due to the homogenous nature of our study population (severe COVID-19 patients admitted to ICU) while the majority of other studies had patients with mild, moderate and severe disease. It has been reported that patients with non-severe disease have a lower level of DDimer as compared to those with severe disease. ${ }^{24}$

Our sample was a homogenous one including only cases with severe disease admitted to intensive care unit. To the best of our knowledge, this is the first study from South Asia on the role of biomarkers in severe COVID-19. We had a relatively small sample size and it was a single-center experience.

\section{Conclusions}

Serum CRP and LDH levels predict mortality in patients with severe COVID-19 and can be used for risk stratification. Lymphopenia, increase in serum ferritin and D-dimers are frequently observed in patients with severe COVID-19 but these may not predict survival. Clinicians caring for patients with COVID-19 should use serum CRP and LDH levels for risk stratification and prognosis.

\section{List Of Abbreviations}




\begin{tabular}{|ll|}
\hline CRP & C-reactive protein \\
\hline COVID-19 & Corona Virus Disease 2019 \\
\hline ESR & Erythrocyte Sedimentation Rate \\
\hline HIS & Hospital information system \\
\hline HMC & Hayatabad Medical Complex \\
\hline ICU & Intensive care unit \\
\hline IL-6 & Interleukin - 6 \\
\hline LDH & Lactate Dehydrogenase \\
\hline RT-PCR & Reverse transcriptase polymerase chain reaction \\
\hline SAA & Serum amyloid A \\
\hline SARS-CoV-2 & Severe acute respiratory syndrome - Corona virus 2 \\
\hline SOP & Standard operating procedures \\
\hline WHO & World Health Organization \\
\hline
\end{tabular}

\section{Declarations}

Ethics approval and consent to participate

This study was approved by Institutional Review Board and Ethical Review Committee of Hayatabad Medical Complex \& Khyber Girls Medical College, Peshawar, Pakistan. The requirement for consent to participate was waived off.

\section{Consent for publication}

Not applicable.

\section{Availability of data and materials}

The datasets used in this study are available from the corresponding author on reasonable request.

\section{Competing interests}

There are no competing interests.

\section{Funding}

Not applicable

\section{Authors' contributions}


All authors had full access to all the data in the study and the corresponding author had final responsibility for the decision to submit for publication. SB, FR, SA, MN contributed to conceiving the concept and study design. MU, AM, HG, MAK, RU, KS and AUH retrieved, reviewed and entered the data. SB analyzed the data. SB, FR, SA, and MN prepared, read and approved the manuscript.

\section{Acknowledgements}

\section{References}

1. Zhou F, Yu T, Du R, et al. Clinical course and risk factors for mortality of adult inpatients with COVID19 in Wuhan, China: a retrospective cohort study. Lancet. 2020;395(10229):1054-62. doi:10.1016/S0140-6736(20)30566-3.

2. W.H.O. Virtual press conference on COVID-19-11 March 2020. https://www.who.int/docs/defaultsource/coronaviruse/transcripts/who-audio-emergencies-coronavirus-press-conference-full-and-final11mar2020.pdf?sfvrsn=cb432bb3_2. Published 2020. Accessed June 28, 2020.

3. WHO WHO Coronavirus Disease. (COVID-19) Dashboard. https://covid19.who.int/? gclid=CjwKCAjw1K75BRAEEiwAd41h10STbAOdEK4U4n0tVe2nMkkHxqRC6zkC9JSOYUa8s5mvPTG2sXQhxoCFsgQAvD_BwE. Published 2020. Accessed August 25, 2020.

4. COVID Portal Pakistan. http://covid.gov.pk/. Published 2020. Accessed August 25, 2020.

5. Ponti G, Maccaferri M, Ruini C, Tomasi A, Ozben T. Biomarkers associated with COVID-19 disease progression. Crit Rev Clin Lab Sci. 2020;57(6):1-11. doi:10.1080/10408363.2020.1770685.

6. Guan W, Ni Z, Hu Y, et al. Clinical characteristics of coronavirus disease 2019 in China. N Engl J Med. 2020;382(18):1708-20. doi:10.1056/NEJMoa2002032.

7. Feng X, Li S, Sun Q, et al. Immune-inflammatory parameters in COVID-19 cases: A systematic review and meta-analysis. Front Med. 2020;7(June):1-14. doi:10.3389/fmed.2020.00301.

8. Chen W, Zheng KI, Liu S, Yan Z, Xu C, Qiao Z. Plasma CRP level is positively associated with the severity of COVID-19. Ann Clin Microbiol Antimicrob. 2020;19:1-7. doi:10.1186/s12941-020-00362-2.

9. Fan BE, Chong VCL, Chan SSW, et al. Hematologic parameters in patients with COVID-19 infection. Am J Hematol. 2020;95(6):E131-4. doi:10.1002/ajh.25774.

10. Ji W, Bishnu G, Shen X, Cai Z. Analysis clinical features of COVID-19 infection in secondary epidemic area and report potential biomarkers in evaluation. 2020:1-10. doi:10.1101/2020.03.10.20033613.

11. Tay MZ, Poh CM, Rénia L, MacAry PA, Ng LFP. The trinity of COVID-19: immunity, inflammation and intervention. Nat Rev Immunol. 2020;20(6):363-74. doi:10.1038/s41577-020-0311-8.

12. Chen G, Wu D, Guo W, et al. Clinical and immunological features of severe and moderate coronavirus disease 2019. J Clin Invest. 2020;130(5):2620-9. doi:10.1172/JCl137244.

13. Zhang J, Dong X, Cao Y, yuan, et al. Clinical characteristics of 140 patients infected with SARS-CoV-2 in Wuhan, China. Allergy Eur J Allergy Clin Immunol. 2020;75(7):1730-41. doi:10.1111/all.14238. 
14. $11 \mathrm{pc}$ Pakistanis have developed protective immunity: study. https://www.dawn.com/news/1575607/11pc-pakistanis-have-developed-protective-immunity-study. Accessed August 25, 2020.

15. World Health Organization. Clinical management of severe acute respiratory infection when COVID19 is suspected (v1.2). 2020:1-21. https://www.who.int/publications-detail/clinical-management-ofsevere-acute-respiratory-infection-when-novel-coronavirus-(ncov)-infection-is-suspected.

16. Huang I, Pranata R. Lymphopenia in severe coronavirus disease-2019 (COVID-19): Systematic review and meta-analysis. J Intensive Care. 2020;8(1):1-10. doi:10.1186/s40560-020-00453-4.

17. Tan L, Wang Q, Zhang D, et al. Lymphopenia predicts disease severity of COVID-19: a descriptive and predictive study. Signal Transduct Target Ther. 2020;5(1):16-8. doi:10.1038/s41392-020-0148-4.

18. Fischer K, Hoffmann P, Voelkl S, et al. Inhibitory effect of tumor cell-derived lactic acid on human T cells. Blood. 2007;109(9):3812-9. doi:10.1182/blood-2006-07-035972.

19. Li Q, Ding X, Xia G, et al. Eosinopenia and elevated C-reactive protein facilitate triage of COVID-19 patients in fever clinic: A retrospective case-control study. EClinicalMedicine. 2020;23:100375. doi:10.1016/j.eclinm.2020.100375.

20. Wang L. C-reactive protein levels in the early stage of COVID-19. Med Mal Infect. 2020;50(4):332-4. doi:10.1016/j.medmal.2020.03.007.

21. Wu C, Chen X, Cai Y, et al. Risk Factors Associated with Acute Respiratory Distress Syndrome and Death in Patients with Coronavirus Disease 2019 Pneumonia in Wuhan, China. JAMA Intern Med. 2020;180(7):934-43. doi:10.1001/jamainternmed.2020.0994.

22. Wu MY, Yao L, Wang Y, et al. Clinical evaluation of potential usefulness of serum lactate dehydrogenase (LDH) in 2019 novel coronavirus (COVID-19) pneumonia. Respir Res. 2020;21(1):171. doi:10.1186/s12931-020-01427-8.

23. Terpos E, Ntanasis-Stathopoulos I, Elalamy I, et al. Hematological findings and complications of COVID-19. Am J Hematol. 2020;95(7):834-47. doi:10.1002/ajh.25829.

24. Polimeni A, Leo I, Spaccarotella C, et al. Prognostic Impact of Coagulopathy in Patients with COVID19: a Meta-analysis of 35 Studies and 6427 Patients. 2020. doi:10.21203/rs.3.rs-31142/v1. 